\title{
Differential Expression of Circulating Inflammatory Proteins Following Sport-Related Traumatic Brain Injury
}

\author{
Ghazala Begum ${ }^{1}$, Rahul Reddy ${ }^{2}$, Kamal M. Yakoub ${ }^{3,4}{ }^{(0)}$, Antonio Belli ${ }^{3,4}$, David J. Davies ${ }^{3,4, *}$ \\ and Valentina Di Pietro ${ }^{3,4}$ \\ 1 Marker Diagnostics Ltd., The BioHub, Edgbaston, Birmingham B15 2SQ, UK; gbegum@markerhealth.co \\ 2 University of Illinois, Chicago, IL 60607, USA; rahulr3@illinois.edu \\ 3 Neuroscience \& Ophthalmology Research Group, Institute of Inflammation \& Ageing, College of Medical \\ and Dental Sciences, University of Birmingham, Edgbaston, Birmingham B15 2TT, UK; \\ K.Yakoub@bham.ac.uk (K.M.Y.); A.Belli@bham.ac.uk (A.B.); V.DiPietro@bham.ac.uk (V.D.P.) \\ 4 National Institute for Health Research Surgical Reconstruction and Microbiology Research Centre, \\ Queen Elizabeth Hospital, Edgbaston, Birmingham B15 2TH, UK \\ * Correspondence: D.J.Davies.1@bham.ac.uk; Tel.: +44-0-121-414-7555
}

Received: 9 January 2020; Accepted: 7 February 2020; Published: 12 February 2020

\begin{abstract}
Sport-related traumatic brain injury (TBI) elicits a multifaceted inflammatory response leading to brain injury and morbidity. This response could be a predictive tool for the progression of TBI and to stratify the injury of which mild TBI is most prevalent. Therefore, we examined the differential expression of serum inflammatory markers overtime and identified novel markers in repetitively concussed athletes. Neuropsychological assessment by Wechsler Adult Intelligence Scale (WAIS) and Immediate Post Concussion Assessment and Cognitive Test (ImPACT) was performed on rugby players and serum was taken from healthy, concussed and repetitively concussed athletes. Serum was also obtained $<1$ week and $>1$ week after trauma and analyzed for 92 inflammatory protein markers. Fibroblast growth factor 21 (FGF21) and interleukin-7 (IL-7) differentiated repetitively concussed athletes. Macrophage chemotactic protein-1 (MCP-1), tumor necrosis factor superfamily member 14 (TNFSF14) were significantly reduced $>1$ week and chemokine (C-X3-C motif) ligand 1 (CX3CL1) upregulated $<1$ week after injury. FGF21 and MCP-1 negatively correlated with symptoms and their severity. We have identified dynamic changes in the inflammatory response overtime and in different classes of concussion correlating with disease progression. This data supports the use of inflammatory biomarkers as predictors of symptom development due to secondary complications of sport-related mTBI.
\end{abstract}

Keywords: mild traumatic brain injury; concussion; neuroinflammation; FGF21; MCP-1

\section{Introduction}

Traumatic brain injury (TBI) causes damaging neurological impairments leading to disability and morbidity. TBI affects young and old, with young victims creating a substantial negative impact to families and wider society with years of lost productivity and an increasing burden on healthcare systems [1,2]. Such is its prevalence that its economic cost to the US is $\$ 56$ billion a year [3]. This large socio-economic burden can lead to poor post trauma follow up exacerbating a patient's injuries. Therefore, there is a need to not only identify therapies, but to also have accurate diagnostic and prognostic monitoring capabilities.

Mild TBI (mTBI) is the most prevalent form of TBI with up to $80 \%$ of patients suffering with adverse symptoms such as sleep disturbances, headaches, nausea, impaired memory, or loss of function [4]. 
mTBI can be defined as head trauma resulting in either memory loss or altered neurological function up to a day following the traumatic ictus or loss of consciousness for under $30 \mathrm{~min}$ [5]. A large proportion of mTBI consists of sport-related concussive (SRC) injury with up to 3.8 million cases reported in the United States annually [6]. There is also a greater risk of these athletes experiencing repetitive concussions which has been associated with the development of neurodegenerative diseases such as Parkinson's, Alzheimer's, and chronic traumatic encephalopathy (CTE) [6-15]. Neurocognitive tests have been developed to diagnose concussion. However, these assessments are expensive, subject to bias due to lack of appropriate baselines and have not yet demonstrated efficacy as prognostic tools [16-18].

Difficulties in developing tools for the prediction of progressive pathology in TBI are confounded by the variability in the anatomical location, extent of the mechanical injury to the brain, as well as the multitude of biological response mechanisms involved. TBI is broadly characterized by 2 phases $[19,20]$. Immediately after impact, the primary phase is associated with shearing and tearing of neural and vascular brain structures and enhanced permeability of the blood-brain barrier. Within minutes start the secondary phase, where danger-associated molecular pattern (DAMPs) molecules are released from damaged cells which stimulate the Toll-like receptor (TLR) [21]. Cytokines and chemokines are also released leading to the recruitment of microglia and peripheral monocytes to the site of injury [22].

In addition, cytotoxic and ischemic responses enhance axonal death and ultimately injury to neurological structures [21]. This is associated with the conversion of monocytes to macrophages and the $\mathrm{T}$ cell production of cytokines. Macrophages are important in removing debris however, they can have a dual effect of allowing tissue repair or additional damage [22]. The inflammatory changes can remain for days to months exacerbating injury in systemic and intracranial systems.

Simultaneously, microglia potentiate neuronal recovery through the production of pro- and anti-inflammatory mediators [23]. This includes the interleukins IL-6 and IL-7 as well as tumor necrosis factor- $\alpha$ (TNF- $\alpha)$ and chemokines macrophage chemotactic protein-1 (MCP-1). Consequently, they display both a neuroprotective and neurodegenerative response [24]. This interplay continues to change and evolve as the secondary response progresses, ultimately leading to increased expression of reactive oxygen species (ROS) in microglia and further cell injury [25]. Therefore, targeting the inflammatory system could provide a potential therapeutic strategy for minimizing post-injury evolution and improving survival [26].

In addition to potential therapies, inflammatory proteins could also be used for the development of biomarkers useful in the clinical assessment of mTBI. Efforts have been focused on quantifying inflammatory markers in easily obtained bodily fluids such as serum, saliva, and urine. It has already been shown that IL- 6 was differentially expressed in serum levels of TBI patients within hours after injury [27] and IL-10 is strongly associated with morbidity [28]. Following extensive protein analysis Cystatin D, AXIN1, and TRAIL were also identified as biomarkers for the early detection of TBI and were further able to differentiate between mild and severe TBI [29]. In addition to immediate changes, inflammatory markers could also be used to track recovery over time in severe traumatic injuries [30].

However, studies investigating the relationship between inflammatory markers and the ability to track the evolution of both symptoms and physiological responses to sports-related concussion (SRC) over time, are limited. Moreover, little has been done to assess the differential expression of the circulating inflammatory response in athletes who have suffered repetitive concussions.

Consequently, in this study we have focused analysis on inflammatory markers in the serum of semi-professional and professional Rugby players who suffered mTBI and repeated mTBI. These samples were obtained less than one week after injury ( $<1$ week) to determine the early inflammatory response and over 1 week ( $>1$ week) following injury to assess longitudinal inflammatory effects. In addition to investigating the inflammatory network in athletes after a single concussion (C), those who suffered repeated concussions (RC) were also investigated. This data has been analyzed in conjunction with and contextualized in relation to cognitive performance and symptom severity, with protein expression as a predictive tool for the evolving inflammatory response seen in mTBI. 


\section{Results}

\subsection{Identifiers of Concussed and Repetitively Concussed Athletes}

The levels of 92 inflammatory markers were measured in the serum from $\mathrm{H}, \mathrm{C}$, and RC athletes whose samples were collected within 2-14 days following their most recent concussion. RC athletes were those players that had received 2 concussions within a 3-month period. Following this analysis, the 3 proteins tumor necrosis factor superfamily member 14 (TNFSF14), fibroblast growth factor 21 (FGF21), and interleukin 7 (IL-7) were found to be altered between the groups (Figure 1). TNFSF14 levels were significantly reduced in $\mathrm{C}$ patients when compared to $\mathrm{H}$ and $\mathrm{RC}$ groups (Figure $1 \mathrm{~A} ; \mathrm{H}=$ $4.38 \pm 0.52, \mathrm{C}=3.44 \pm 1.10, \mathrm{RC}=3.61 \pm 0.85 ; \mathrm{H}$ vs. $\mathrm{C} p=0.0278$ ). Following the same analysis two clear markers were identified for RC athletes differentiating them from healthy and single concussion groups. In these occurrences FGF21 was significantly downregulated in RC serum (Figure $1 \mathrm{~B} ; \mathrm{H}=4.65$ $\pm 1.25, \mathrm{C}=4.05 \pm 1.32, \mathrm{RC}=2.89 \pm 0.69 ; \mathrm{H}$ vs. $\mathrm{RC} p=0.037)$ and IL-7 was significantly increased in $\mathrm{RC}$ athletes (Figure $1 \mathrm{C} ; \mathrm{H}=4.78 \pm 0.45, \mathrm{C}=4.83 \pm 0.59, \mathrm{RC}=5.47 \pm 0.35 ; \mathrm{H}$ vs. $\mathrm{RC} p=0.043, \mathrm{C}$ vs. $\mathrm{RC}$ $p=0.049)$.
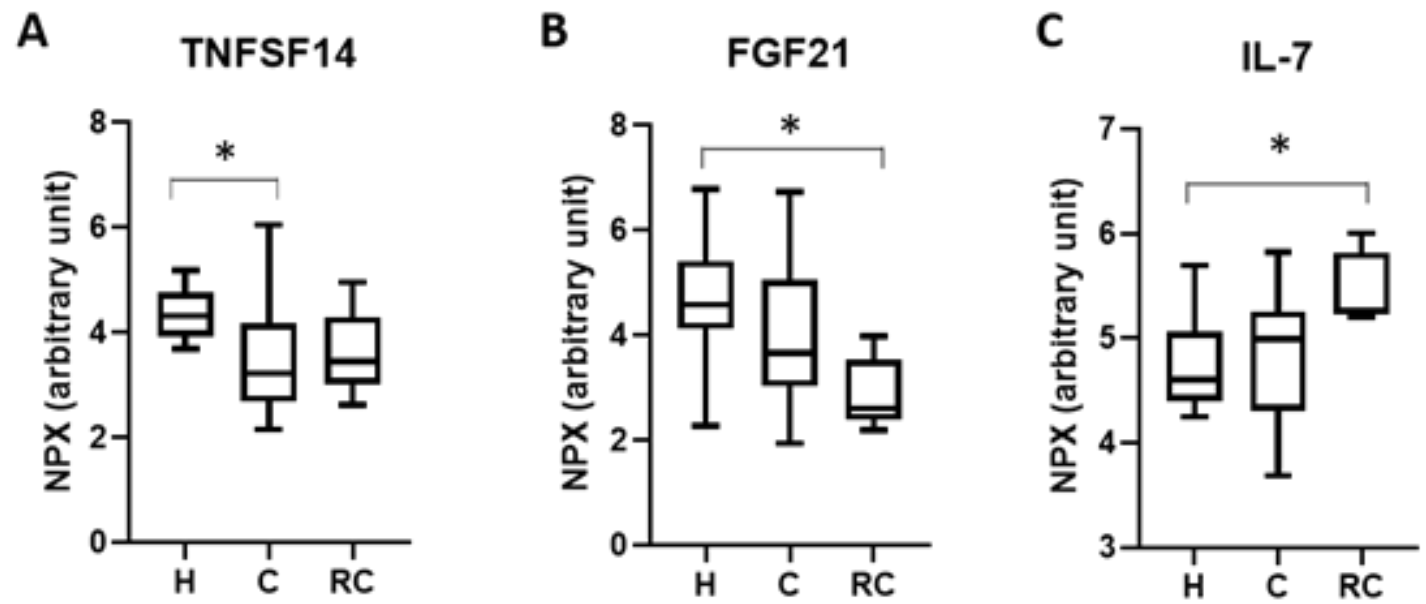

Figure 1. Differentially expressed proteins in human serum from healthy $(\mathrm{H})$, concussed $(\mathrm{C})$, and repetitively concussed (RC) patients. TNFSF14 (A) was found to be significantly reduced in concussed patients when compared to healthy individuals. In contrast FGF21 (B) was significantly downregulated and IL-7 (C) was significantly upregulated in repetitively concussed patients. Data is presented as the mean \pm SE and was tested for normality followed by a one-way Anova and a tukey post hoc test where ${ }^{*} p<0.05 . \mathrm{H}=12 \mathrm{C}=18 \mathrm{RC}=5$.

\subsection{Differential Expression of Biomarkers at Early and Late Timepoints Following Concussion}

In order to determine if there are any changes in biomarkers indicative of ongoing mTBI pathology in the extended post-injury time window, we compared the expression of markers in athletes less than a week following concussion and those over a week (average 60 days following injury). Three markers were identified at the different time points. Both MCP-1 (Figure $2 \mathrm{~A} ; \mathrm{H}=11.46 \pm 0.43,<1$ week $=11.16$ $\pm 0.50,>1$ week $=10.90 \pm 0.41$; vs. $>1$ week $p=0.030$ ) and TNFSF14 (Figure $2 \mathrm{~B} ; \mathrm{H}=4.38 \pm 0.52,<1$ week $=3.56 \pm 1.02,>1$ week $=3.28 \pm 1.03 ; \mathrm{H}$ vs. $>1$ week $p=0.038$ ) were significantly reduced in the serum of patients $>1$ week after the initial injury when compared to controls. The only marker found to be significantly altered in patients that presented $<1$ week after injury was the chemokine $(\mathrm{C}-\mathrm{X} 3-\mathrm{C}$ motif) ligand 1 (CX3CL1) which was increased when compared to $\mathrm{H}$ participants (Figure $2 \mathrm{C} ; \mathrm{H}=7.07$ \pm 0.29 , <1 week $=7.43 \pm 0.39,>1$ week $=7.32 \pm 0.37, p=0.027$ ). 
A

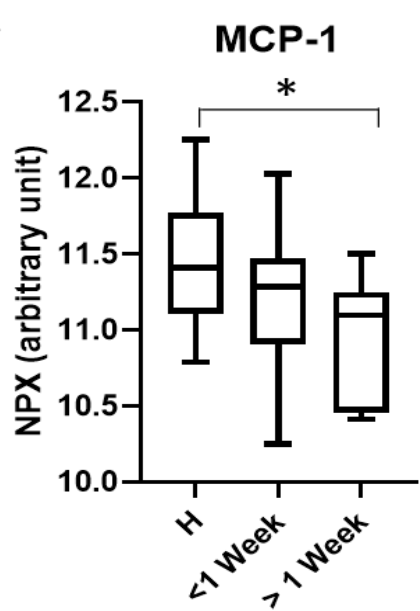

B

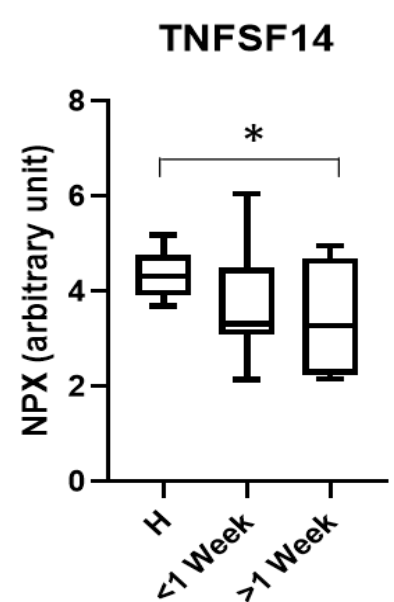

C

CX3CL1

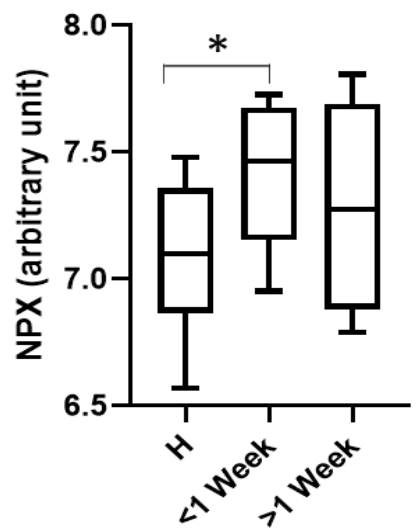

Figure 2. Changes in serum protein levels following analysis under $(<1$ week) and over a week $(>1$ week) after injury when compared to healthy $(\mathrm{H})$ athletes. MCP-1 (A) and TNFSF14 (B) levels were significantly reduced in serum taken from patients $>1$ week after injury. CX3CL1 (C) was significantly upregulated in serum taken $<1$ week following injury when compared to $\mathrm{H}$. Data is presented as the mean \pm SE and was tested for normality followed by a one-way Anova and a tukey post hoc test where $* p<0.05 . \mathrm{H}=12,<1$ week $=11,>1$ week $=7$.

\subsection{Clinical Assessment of Secondary Symptoms Following mTBI}

Concussed patients displayed a range of symptoms with headaches being the most commonly reported at $63 \%$ (Table 1: $n=51$ patients). This was followed by fatigue (29\%), fogginess $(29 \%)$, drowsiness $(27 \%)$, and having trouble falling asleep (27\%). Patients were clinically assessed by the WAIS symbol search and ImPACT tests. Despite the range of criteria that the WAIS assessment covered only the number of symbols entered was found to be significantly lower in concussed patients (Figure 3A; $\mathrm{H}=43.17 \pm 7.07, \mathrm{C}=36.67 \pm 6.45, p=0.0196$ ). The ImPACT test revealed that the amount of impulse control was significantly reduced in concussed patients (Figure 3B; $\mathrm{H}=5.167 \pm 2.79, \mathrm{C}=$ $2.533 \pm 2.20, p=0.0110$ ) and their symptom score was higher when compared to controls (Figure 3C; $\mathrm{H}$ $=1.833 \pm 3.19, \mathrm{C}=9.733 \pm 11.79, p=0.0336$ ).

\section{A}

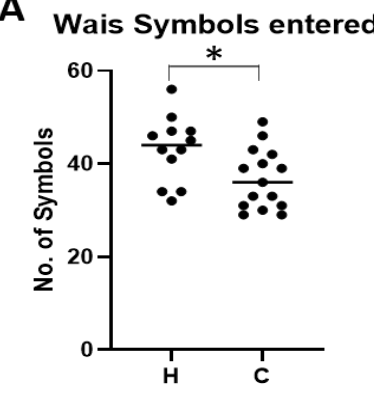

B

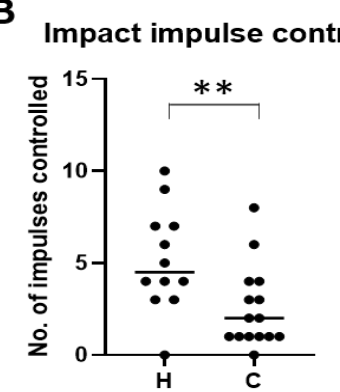

C

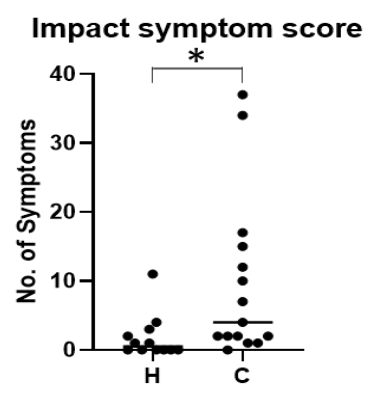

Figure 3. Outcomes of the Wechsler Adult Intelligence Scale (WAIS) symbol search and Impact test for concussion for the patients within this study. Following comprehensive clinical assessment of the WAIS symbol search and Impact test on healthy $(\mathrm{H})$ and concussed $(\mathrm{C})$ athletes it was found that the number of symbols entered (A), the impact on impulse control (B) and the impact symptom score (C) were significantly altered. Data is represented as the mean and individual data points were data was analyzed for significance using the unpaired T test where ${ }^{*} p<0.05,{ }^{* *} p<0.01$. WAIS symbol search $n$ : $\mathrm{H}=12, \mathrm{C}=15$. Impact test $n: \mathrm{H}=12 \mathrm{C}=15$. 
Table 1. The table represents the most common symptoms reported by patients following concussion in the study. Headaches were highly reported followed by fatigue, feeling foggy, drowsiness, and having trouble falling asleep. In a few cases nausea was also present. Data is presented as a percentage of total number of patients. Concussed $=51$.

\begin{tabular}{cc}
\hline Symptoms & Concussed (Number of Patients Reporting the Symptom \%) \\
\hline Headache & 63 \\
Fatigue & 29 \\
Foggy & 29 \\
Drowsiness & 27 \\
Trouble falling asleep & 27 \\
Balance & 23 \\
Dizziness & 19 \\
Irritability & 19 \\
Nausea & 10 \\
\hline
\end{tabular}

\subsection{FGF21 and MCP-1 Correlate with Symptom Severity and Cognitive Performance}

To determine if the expression of inflammatory proteins correlates with clinical symptoms of secondary TBI all proteins were compared to clinical neuropsychological data using Spearman's correlation coefficient. Of these proteins, serum expression of FGF21 (Figure 4) and MCP-1 (Figure 5) were the most indicative of clinical characteristics. Low levels of circulating FGF21 was associated with an increase in the number of reported symptoms (Figure 4A; $r=-0.484, p=0.008$ ) as well as greater severity of the symptoms (Figure $4 \mathrm{~B} ; r=-0.433, p=0.019$ ). Of these symptoms reported headaches showed a significant negative correlation with protein expression (Figure 4C; $r=-0.579, p=0.0003$ ). FGF21 expression was also negatively correlated with a larger impact on impulse control (Figure 4D; $r=-0.370, p=0.048$ ).

A

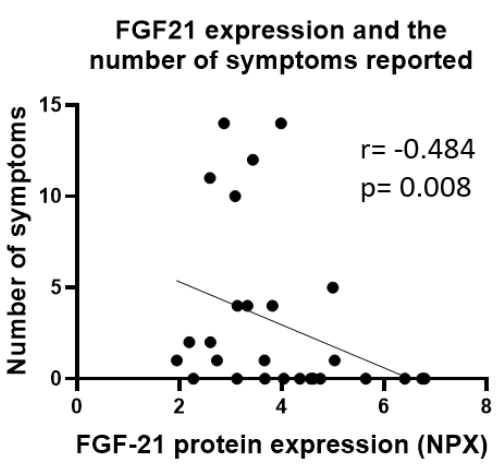

C

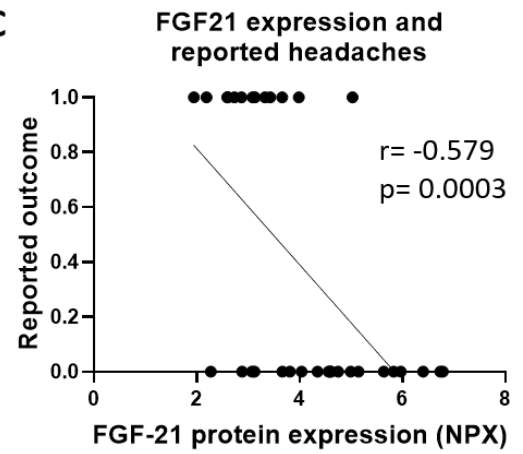

B

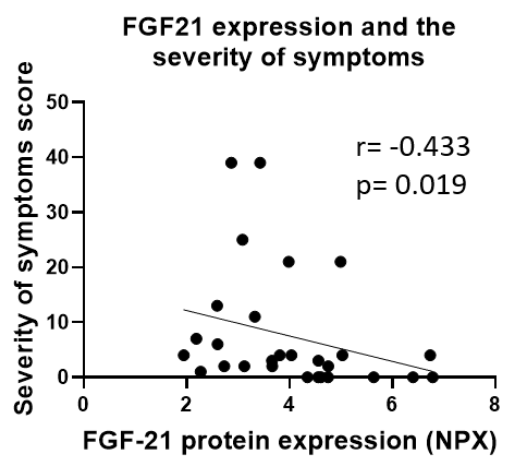

D

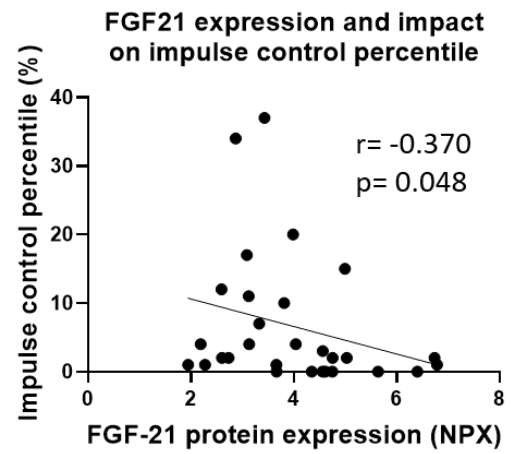

Figure 4. Fibroblast growth factor 21 (FGF21) protein expression correlated to clinical data. Reduced FGF21 protein expression was associated with increases in the (A) number and (B) severity of the symptoms such as (C) headaches. There was also a correlation of low levels of FGF21 and the (D) impact on impulse control. Data was analyzed according to Spearman's correlation coefficient where the number of pairs $=29$ and $p<0.05$. 
A

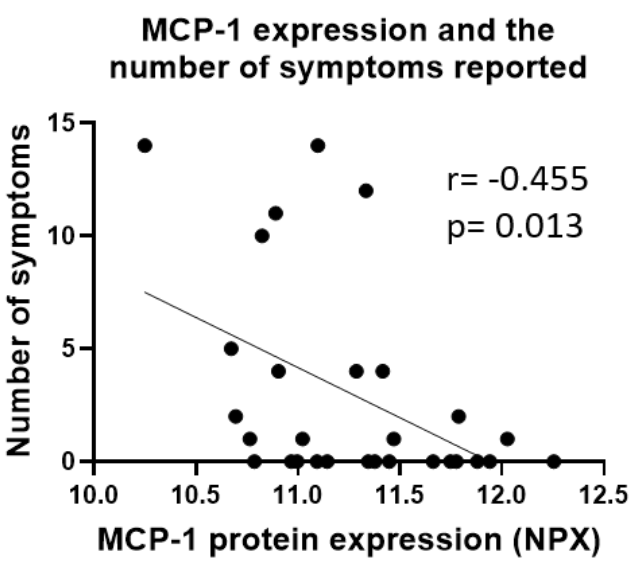

C
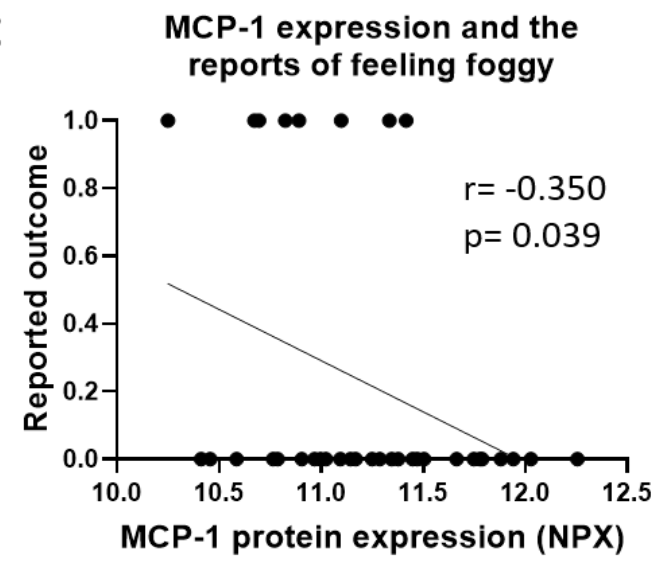

$\mathbf{E}$

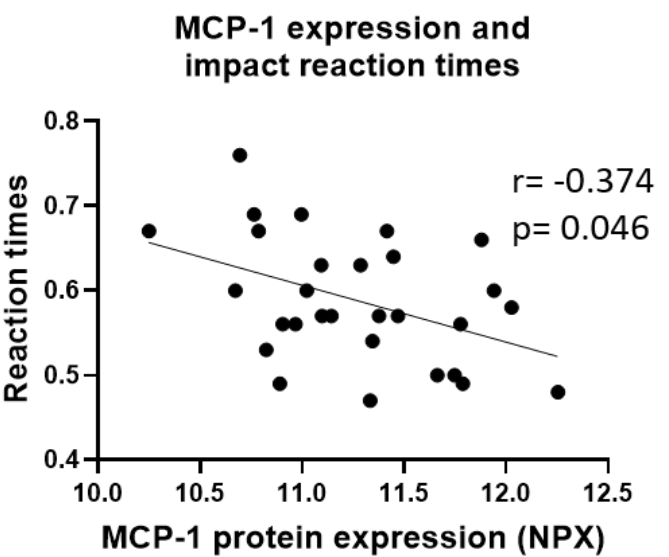

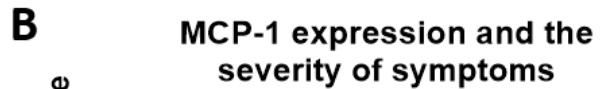

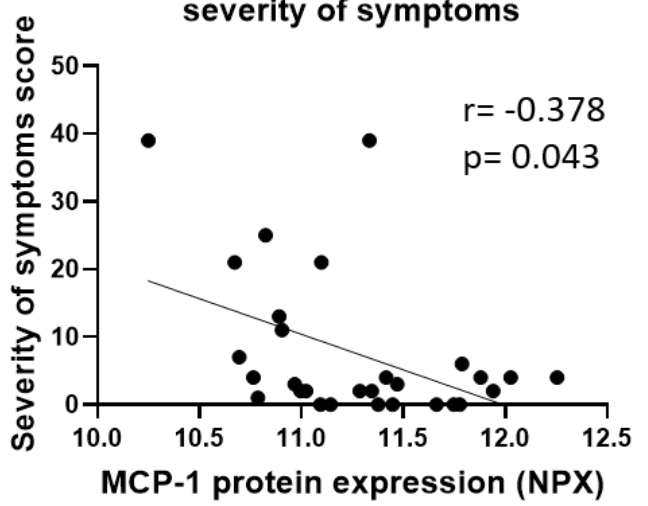

MCP-1 expression and
reports of poor balance

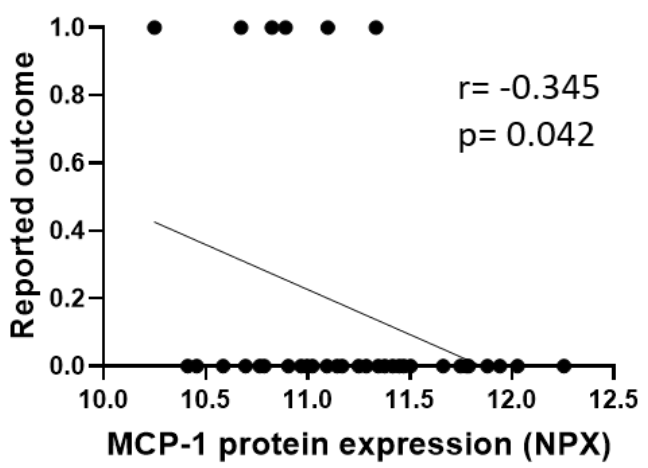

Figure 5. Macrophage chemotactic protein-1 (MCP-1) protein expression correlated to clinical data. Reduced MCP-1 expression was associated with increases in the number of (A) reported symptoms and their (B) severity. This included feeling (C) foggy and reports of (D) poor balance. There was also a significant negative correlation between MCP-1 expression and (E) reaction times. Data was analyzed according to Spearman's correlation coefficient where the number of pairs $=29$ and $p<0.05$.

Reduced serum levels of MCP-1 were also related to an increase in the number (Figure 5A; $r=0.455, p=0.013$ ) and severity of symptoms (Figure $5 \mathrm{~B} ; r=-0.378, p=0.043$ ) reported. Low levels of MCP-1 were correlated with greater numbers of patients feeling foggy (Figure $5 C ; r=-0.350, p=0.039$ ) and having poor balance (Figure 5D; $r=-0.345, p=0.042$ ). Additionally, reduced serum MCP-1 levels were found to be consistent with increases in the time to react (Figure $5 \mathrm{E} ; r=-0.374, p=0.046$ ). 


\section{Discussion}

In this study we have provided further evidence of circulating inflammatory biomarkers correlating with symptoms following mTBI in the serum of athletes who have had multiple concussions. Many investigations have analyzed the immediate inflammatory response after TBI [19-21]. This data may aid our understanding of the complex mechanism following mTBI leading to the development of accurate diagnostic and prognostic tools to better define the period of injury and guide a safe return to play objective protocol.

The injury burden of mTBI may have potentially caused the participants in our study to exhibit reduced cognitive performance such as impaired memory and impulse control as well as the development of symptoms including headaches, fatigue and sleep disturbances. Processing speed and visual processing was measured by the WAIS IV symbol search which is an assessment of head injury of all etiologies, we also utilized the computerized ImPACT test which was developed for athletes [18,31] in this investigation. This allowed us to identify changes in motor speed, reaction time and impulse control which are key components in the ImPACT assessment. However, whilst we observed some changes in cognitive performance the validity of the test for clinical use is still unclear and therefore, as others have found it may not be accurate enough for diagnosis of mTBI alone [18,32-34].

The secondary inflammatory response following concussion is regulated by pro- and anti-inflammatory cytokines [21,22]. Expression patterns of these cytokines is associated with the different forms and severity of TBI $[29,35]$. In our study we were able to assess variances in the expression of 92 circulating inflammatory proteins in athletes suffering from repetitive concussions within a three-month period. Of these candidate markers FGF21 and IL-7 were significantly altered. FGF21 is important in the process of cell proliferation including that of oligodendrocyte precursor cells (OPC) [36] and is involved in oligodendrocyte development and remyelination [37,38]. In a murine model of TBI, FGF21 was able to protect the blood-brain barrier by forming a complex with its receptors [39]. It has also been shown to enhance angiogenesis and the restoration of functional anatomy in the brain [40]. Consequently, a decrease in circulating FGF21 following repetitive concussion could lead to deleterious effects in cerebral tissue. This was evidenced by the significant negative correlation of FGF21 protein expression and the number of symptoms and their severity including headaches as reported in our study. A central neurological affect is further supported by studies within the literature that have observed FGF21 crossing the blood-brain barrier [41]. In addition to its potential as a biomarker for repetitive concussion and its potential cumulative effect on neurological pathology, FGF21 could be an effective therapeutic strategy for the guidance treatment of repetitive TBI.

We demonstrate that IL-7 was also significantly increased in the RC athletes when compared to controls. This protein is important for the development and survival of T-lymphocytes and it can enhance the production of pro-inflammatory cytokines [42]. Interestingly increased IL-7 in the serum has been found in patients with multiple sclerosis [43], a demyelinating disease of the central nervous system. This could be due to IL-7s ability to upsurge the accumulation of activated microglia/macrophages leading to secondary damage and regeneration failure [44]. Therefore, it could be hypothesized that augmented levels of IL-7 in RC patients could be a poor prognostic indicator in their recovery, as has been evidenced in another study where increased IL-7 was a positive prognostic factor in the development of posttraumatic depression following TBI [45].

The protein TNFSF14, was the only marker able to differentiate between concussed and repetitively concussed patients. In C patient cohort, the decrease in TNFSF14 serum expression was also found to be attenuated overtime. This protein is known to trigger apoptosis in tumor cells as well as regulating the proliferation of T cells [46-48]. TNFSF14 has been identified as a risk gene for multiple sclerosis [49] however, little is known about its affects in TBI and further investigation of this relationship is required.

We also investigated changes in protein expression overtime in athletes that had received a single concussion. Our data showed significant changes in MCP-1 (also known as CCL2), which is one of the most well correlated TBI proteins $[35,50]$. MCP-1 has been shown to be expressed in the CNS by astrocytes [51,52]. It can attract cells including macrophages and microglia via inflammatory 
stimuli [50]. This recruitment enhances the inflammatory response leading to further degeneration and as such central inhibition of MCP-1 has been shown to reduce neuronal loss [53]. Many investigations have shown an increase in MCP-1 expression within 5 days following TBI [50,52,54]. In contrast to this, we found serum MCP-1 levels attenuated overtime negatively correlating with patients feeling foggy and having poor balance. The decrease in MCP-1 could be a protective reaction preventing further neurological injury. However, most of these studies have been carried out in animal models over shorter periods of time following injury. They were also carried out in a range of different levels and methods of injury.

Differential expression of the chemokine CX3CL1 (also known as Fractalkine) was also found. CX3CL1 has been shown to have an important role in the CNS where it is present in many areas including the cerebral cortex, amygdala, and the hippocampus [55]. In these areas it maintains the dynamics between neurons and microglia [56]. During neurotoxicity, CX3CL1 has been found to protect microglia by stimulating anti-apoptotic $\mathrm{Bcl}$ in addition to producing a phagocytic response to inhibit neurotoxic stimuli [57]. Previous studies have shown changes in CX3CL1 in both the CSF and the serum of patients suffering TBI however, there are conflicting outcomes in whether its expression increases of decreases $[58,59]$. In our study the increase observed within a week after injury could be indicative of CX3CL1 acting to increase microglia activity in response to neurotoxicity. CX3CL1 therefore, is a potential biomarker and target for therapeutic intervention in mTBI. However, the data presented in this manuscript is within the discovery phase and all the candidate markers would need to be further investigated within a larger cohort to determine their suitability as biomarkers of mTBI.

We have identified changes in the expression of inflammatory proteins that could be further developed as diagnostic tools for the resolution of the evolving injury within sports-related mTBI patients and in those who have suffered repetitive concussion. This included FGF21 and MCP-1 whose expression negatively correlated with symptom severity and cognitive performance. These proteins all have an emerging role in the pathogenesis of mTBI and could also be utilized for therapeutic advancement.

\section{Materials and Methods}

\subsection{Study Approval}

Study participants were recruited through the Birmingham concussion clinic at the Queen Elizabeth Hospital Birmingham (QEHB) or at the University of Birmingham (UoB). (UK), as part of the RECOS (The REpetitive COncussion in Sport) (Ethics Ref. REC 17/EE/0275, 22 September 2017) [60]. Written informed consent was received from participants prior to inclusion in the study.

\subsection{Recruitment}

Male and female athletes aged 16-34 years, participating in professional and semi-professional Rugby who have been positively diagnosed as having a concussion along with a normal neurological objective examination at assessment, were enrolled in this study. In addition to those that had suffered single concussions, we also recruited athletes that had suffered 2 concussions within a 3-month period. These athletes had an initial concussive event followed by another one within 3 months. Following their last concussion, samples were taken when they first came to the clinic, between 2-14 days. Individuals who require hospital admission after initial assessment for their TBI, presenting intracranial blood, brain tissue injury, or non-TBI related pathologies on initial CT/MR scan, any history of neurodegenerative pathology or history of chronic alcohol or drug abuse were excluded. In addition, age matched controls, who have not received any concussion in the previous 3 months, were recruited as healthy controls $(\mathrm{H})$. Blood samples were taken $<1$ week after or $>1$ week after injury. Of these samples, one athlete had taken paracetamol $24 \mathrm{~h}$ before entering the clinic.

Clinical, demographic (Table 2), neuropsychometric and imaging parameters were collected for each subject on the day that they came to report their concussions to the clinic, including, 
among others, parameters forming part of The Sport Concussion Assessment Tool-5th Edition (SCAT 5) (e.g., symptoms inventory, injury data, balance errors, and immediate memory and recall tests) [61], concussion history, the Immediate Post-Concussion Assessment and Cognitive Testing battery (ImPACT-FDA approved computerized neuropsychometric suite for sport concussion) [31], and the Wechsler Adult Intelligence Scale version IV symbol search module (WAIS-IV symbol search) [32].

Table 2. Patient demographics. $\mathrm{H}=$ healthy controls, $\mathrm{C}=$ Single concussion, $\mathrm{RC}=$ repetitively concussed, $<1$ week $=$ athletes with a single concussion analyzed less than one week from injury, $>1$ week $=$ athletes with a single concussion analyzed more than one week from injury.

\begin{tabular}{cccccc}
\hline Characteristics & H $(n=12)$ & C $(n=18)$ & RC $(n=5)$ & $<$ 1 Week $(n=11)$ & $>$ 1 Week $(n=7)$ \\
\hline Age (years; Mean \pm SD) & $25.5 \pm 5.9$ & $27.2 \pm 4.9$ & $24.5 \pm 3.2$ & $28.4 \pm 4.9$ & $24.4 \pm 4.1$ \\
Gender $(\mathrm{M} / \mathrm{F})$ & $10 / 2$ & $17 / 1$ & $4 / 1$ & $11 / 0$ & $6 / 1$ \\
\hline
\end{tabular}

\subsection{Blood Collection and Processing}

Samples were collected from non-concussed healthy athletes, athletes who had suffered a concussion with Peripheral venous blood samples were obtained from patients following admission between $2-5$ days ( $<1$ week) and 15-75 days ( $>1$ week) after the initial trauma and processed within $2 \mathrm{~h}$ after venepuncture. Samples were kept at room temperature for $30 \mathrm{~min}$ after which they were centrifuged at $3000 \mathrm{rpm}$ for $10 \mathrm{mins}$ at $4{ }^{\circ} \mathrm{C}$. Serum was separated and stored at $-80^{\circ} \mathrm{C}$ until further use.

\subsection{Multiplex Protein Assay}

Serum expression of 92 inflammatory markers were analyzed using the Proseek Multiplex Inflammation I assay (Olink Bioscience, Uppsala, Sweden) as described previously (Table 3; 29). Briefly, according to the manufacturers protocol, $1 \mu \mathrm{L}$ of serum was incubated at $8^{\circ} \mathrm{C}$ overnight with antibodies labelled with DNA nucleotides. This was then combined with and extension mix in a PCR plate. These plates underwent a $5^{\prime}$ incubation followed by 17 cycles of DNA amplification. Samples were added to a detection mix and loaded onto a primed 96.96 Dynamic Array IFC (Fluidigm, CA, USA) and read in the Fluidigm Biomark reader. Data were then analyzed using the Olink Wizard for GenEx software (Olink) and calculated from Ct values. Protein expression were normalized and presented as normalized protein expression (NPX). NPX units are inverted to $\mathrm{Ct}$ values and as such high NPX values are indicative of high protein levels.

Table 3. 92 inflammatory markers contained within the Proseek Multiplex inflammation assay (Olink Bioscience, Uppsala, Sweden).

\begin{tabular}{ccccc}
\hline $\begin{array}{c}\text { Adenosine } \\
\text { Deaminase (ADA) }\end{array}$ & Caspase 8 (CASP-8) & $\begin{array}{c}\text { Interleukin-12 } \\
\text { subunit beta } \\
\text { (IL-12B) }\end{array}$ & $\begin{array}{c}\text { Latency-associated } \\
\text { peptide transforming } \\
\text { growth factor beta 1 } \\
\text { (LAP TGF-beta-1) }\end{array}$ & $\begin{array}{c}\text { STAM-binding protein } \\
\text { (STAMPB) }\end{array}$ \\
\hline Artemin (ARTN) & $\begin{array}{c}\text { CUB } \\
\text { domain-containing } \\
\text { protein 1 (CDCP1) }\end{array}$ & $\begin{array}{c}\text { Interleukin-13 } \\
\text { (IL-13) }\end{array}$ & $\begin{array}{c}\text { Leukemia inhibitory } \\
\text { factor (LIF) }\end{array}$ & Stem cell factor (SCF) \\
\hline Axin-1 (AXIN1) & Cystatin D (CST5) & $\begin{array}{c}\text { Interleukin-15 } \\
\text { receptor subunit } \\
\text { alpha (IL-15RA) }\end{array}$ & $\begin{array}{c}\text { Leukemia inhibitory } \\
\text { factor receptor (LIF-R) }\end{array}$ & $\begin{array}{c}\text { Sulfotransferase 1A1 } \\
\text { (ST1A1) }\end{array}$ \\
\hline $\begin{array}{c}\text { Beta-nerve growth } \\
\text { factor (Beta-NGF) }\end{array}$ & $\begin{array}{c}\text { Delta and } \\
\text { epidermal growth } \\
\text { factor-related } \\
\text { receptor (DNER) }\end{array}$ & $\begin{array}{c}\text { Interleukin-17A } \\
\text { (IL-17A) }\end{array}$ & $\begin{array}{c}\text { Macrophage } \\
\text { colony-stimulating factor } \\
\text { 1(CSF-1) }\end{array}$ & $\begin{array}{c}\text { Th cell surface } \\
\text { glycoprotein CD6 } \\
\text { isoform (CD6) }\end{array}$ \\
\hline
\end{tabular}


Table 3. Cont.

\begin{tabular}{|c|c|c|c|c|}
\hline $\begin{array}{c}\text { Brain-derived } \\
\text { neurotrophic factor } \\
\text { (BDNF) }\end{array}$ & Eotaxin-1 (CCL11) & $\begin{array}{l}\text { Interleukin-17C } \\
\quad \text { (IL-17C) }\end{array}$ & $\begin{array}{c}\text { Matrix } \\
\text { metalloproteinase-1 } \\
(\mathrm{MMP}-1)\end{array}$ & $\begin{array}{c}\text { T-cell surface } \\
\text { glycoprotein CD5 } \\
\text { (CD5) }\end{array}$ \\
\hline $\begin{array}{l}\text { C-C motif } \\
\text { chemokine } 19 \\
\text { (CCL19) }\end{array}$ & $\begin{array}{c}\text { Eukaryotic } \\
\text { translation } \\
\text { initiation factor } \\
\text { 4E-binding protein } \\
1 \text { (4E-BP1) }\end{array}$ & $\begin{array}{l}\text { Interleukin-18 } \\
\quad(\text { IL-18) }\end{array}$ & $\begin{array}{c}\text { Matrix } \\
\text { metalloproteinase-10 } \\
(\text { MMP-10) }\end{array}$ & $\begin{array}{l}\text { Thymic stromal } \\
\text { lymphopoietin (TSLP) }\end{array}$ \\
\hline $\begin{array}{l}\text { C-C motif } \\
\text { chemokine } 20 \\
\text { (CCL20) }\end{array}$ & $\begin{array}{l}\text { Fibroblast growth } \\
\text { factor } 19 \text { (FGF-19) }\end{array}$ & $\begin{array}{l}\text { Interleukin-18 } \\
\text { receptor 1 (IL-18R1) }\end{array}$ & $\begin{array}{l}\text { Monocyte chemotactic } \\
\text { protein } 1(\mathrm{MCP}-1)\end{array}$ & TNF-beta (TNFB) \\
\hline $\begin{array}{l}\text { C-C motif } \\
\text { chemokine } 23 \\
\text { (CCL23) }\end{array}$ & $\begin{array}{l}\text { Fibroblast growth } \\
\text { factor } 21 \text { (FGF-21) }\end{array}$ & Interleukin-2 (IL-2) & $\begin{array}{l}\text { Monocyte chemotactic } \\
\text { protein } 2(\mathrm{MCP}-2)\end{array}$ & $\begin{array}{c}\text { TNF-related } \\
\text { activation-induced } \\
\text { cytokine (TRANCE) }\end{array}$ \\
\hline $\begin{array}{l}\text { C-C motif } \\
\text { chemokine } 25 \\
\text { (CCL25) }\end{array}$ & $\begin{array}{l}\text { Fibroblast growth } \\
\text { factor } 23 \text { (FGF-23) }\end{array}$ & $\begin{array}{l}\text { Interleukin-2 } \\
\text { receptor subunit } \\
\text { beta (IL-2RB) }\end{array}$ & $\begin{array}{l}\text { Monocyte chemotactic } \\
\text { protein } 3(\mathrm{MCP}-3)\end{array}$ & $\begin{array}{l}\text { TNF-related } \\
\text { apoptosis-inducing } \\
\text { ligand (TRAIL) }\end{array}$ \\
\hline $\begin{array}{l}\text { C-C motif } \\
\text { chemokine } 28 \\
\text { (CCL28) }\end{array}$ & $\begin{array}{l}\text { Fibroblast growth } \\
\text { factor } 5(\mathrm{FGF}-5)\end{array}$ & $\begin{array}{l}\text { Interleukin-20 } \\
\quad(\text { IL-20) }\end{array}$ & $\begin{array}{l}\text { Monocyte chemotactic } \\
\text { protein } 4(\mathrm{MCP}-4)\end{array}$ & $\begin{array}{l}\text { Transforming growth } \\
\text { factor alpha } \\
\text { (TGF-alpha) }\end{array}$ \\
\hline $\begin{array}{l}\text { C-C motif } \\
\text { chemokine } 3 \\
\text { (CCL3) }\end{array}$ & $\begin{array}{l}\text { Fms-related } \\
\text { tyrosine kinase } 3 \\
\text { ligand (Flt3L) }\end{array}$ & $\begin{array}{l}\text { Interleukin-20 } \\
\text { receptor subunit } \\
\text { alpha (IL-20RA) }\end{array}$ & $\begin{array}{l}\text { Natural killer cell } \\
\text { receptor 2B4 (CD244) }\end{array}$ & $\begin{array}{l}\text { Tumor necrosis factor } \\
\text { (Ligand) superfamily, } \\
\text { member } 12 \text { (TWEAK) }\end{array}$ \\
\hline $\begin{array}{l}\text { C-C motif } \\
\text { chemokine } 4 \\
(\text { CCL4) }\end{array}$ & $\begin{array}{l}\text { Fractalkine } \\
\text { (CX3CL1) }\end{array}$ & $\begin{array}{c}\text { Interleukin-22 } \\
\text { receptor subunit } \\
\text { alpha-1 (IL-22 RA1) }\end{array}$ & Neurotrophin-3 (NT-3) & $\begin{array}{l}\text { Tumor necrosis factor } \\
\text { (TNF) }\end{array}$ \\
\hline $\begin{array}{l}\text { C-X-C motif } \\
\text { chemokine } 1 \\
(\mathrm{CXCL} 1)\end{array}$ & $\begin{array}{c}\text { Glial cell } \\
\text { line-derived } \\
\text { neurotrophic factor } \\
\text { (hGDNF) }\end{array}$ & $\begin{array}{l}\text { Interleukin-24 } \\
\quad(\text { IL-24) }\end{array}$ & Neurturin (NRTN) & $\begin{array}{l}\text { Tumor necrosis factor } \\
\text { ligand superfamily } \\
\text { member } 14 \text { (TNFSF14) }\end{array}$ \\
\hline $\begin{array}{l}\text { C-X-C motif } \\
\text { chemokine } 10 \\
\text { (CXCL10) }\end{array}$ & $\begin{array}{l}\text { Hepatocyte growth } \\
\text { factor (HGF) }\end{array}$ & $\begin{array}{l}\text { Interleukin-33 } \\
\quad \text { (IL-33) }\end{array}$ & Oncostatin-M (OSM) & $\begin{array}{l}\text { Tumor necrosis factor } \\
\text { receptor superfamily } \\
\text { member } 9 \text { (TNFRSF9) }\end{array}$ \\
\hline $\begin{array}{l}\text { C-X-C motif } \\
\text { chemokine } 11 \\
(\mathrm{CXCL11)}\end{array}$ & $\begin{array}{l}\text { Interferon gamma } \\
\text { (IFN-gamma) }\end{array}$ & Interleukin-4 (IL-4) & Osteoprotegerin (OPG) & $\begin{array}{c}\text { Urokinase-type } \\
\text { plasminogen activator } \\
\text { (uPA) }\end{array}$ \\
\hline $\begin{array}{l}\text { C-X-C motif } \\
\text { chemokine } 5 \\
(\text { CXCL5) }\end{array}$ & $\begin{array}{l}\text { Interleukin-1 } 1 \alpha \\
\quad(\text { IL- } 1 \alpha)\end{array}$ & Interleukin-5 (IL-5) & $\begin{array}{l}\text { Programmed cell death } 1 \\
\text { ligand } 1 \text { (PD-L1) }\end{array}$ & $\begin{array}{l}\text { Vascular endothelial } \\
\text { growth factor A } \\
\text { (VEGF-A) }\end{array}$ \\
\hline $\begin{array}{l}\text { C-X-C motif } \\
\text { chemokine } 6 \\
(\text { CXCL6) }\end{array}$ & $\begin{array}{l}\text { Interleukin-10 } \\
\quad \text { (IL-10) }\end{array}$ & Interleukin-6 (IL-6) & $\begin{array}{l}\text { Protein S100-A12 } \\
\text { (EN-RAGE) }\end{array}$ & \\
\hline $\begin{array}{l}\text { C-X-C motif } \\
\text { chemokine } 9 \\
\text { (CXCL9) }\end{array}$ & $\begin{array}{l}\text { Interleukin-10 } \\
\text { receptor subunit } \\
\text { alpha (IL-10RA) }\end{array}$ & Interleukin-7 (IL-7) & $\begin{array}{l}\text { Signaling lymphocytic } \\
\text { activation molecule } \\
\text { (SLAMF1) }\end{array}$ & \\
\hline $\begin{array}{l}\text { CDL40 receptor } \\
\text { (CD40) }\end{array}$ & $\begin{array}{l}\text { Interleukin-10 } \\
\text { receptor subunit } \\
\text { beta (IL-10RB) }\end{array}$ & Interleukin-8 (IL-8) & $\begin{array}{l}\text { SIR2-like protein } 2 \\
\text { (SIRT2) }\end{array}$ & \\
\hline
\end{tabular}

\subsection{Statistical Analysis}

All data is presented as the mean \pm standard deviation. Comparison of protein expression between the control and concussion groups and the time points was first tested for distribution using the Shapiro Wilks test after which a one-way ANOVA with Tukey post hoc test was performed, where $p<0.05$. To identify correlations between protein expression and cognitive performance and symptoms detailed in the WAIS and ImPACT tests, data were analyzed using the Spearman's correlation coefficient where $p$ $<0.05$. In order to generate correlations with symptoms the presentation of a symptom was scored as 1 
and where the symptom was not apparent it was scored as 0. All data was analyzed using GraphPad Prism 8 (GraphPad Inc., San Diego, CA, USA).

Author Contributions: Conceptualization, G.B. and V.D.P.; Data curation, G.B., K.M.Y., D.J.D. and V.D.P.; Formal analysis, G.B. and R.R.; Funding acquisition, A.B. and V.D.P.; Investigation, G.B. and V.D.P.; Methodology, G.B., K.M.Y., A.B., D.J.D. and V.D.P.; Project administration, V.D.P.; Resources, D.J.D. and V.D.P.; Software, G.B. and V.D.P.; Supervision, V.D.P.; Validation, G.B., Rahul Reddy and V.D.P.; Visualization, R.R.; Writing—original draft, G.B. and V.D.P.; Writing—review and editing, G.B., R.R., K.M.Y., D.J.D. and V.D.P. All authors have read and agreed to the published version of the manuscript.

Funding: This research was funded by the National Institute for Health Research (NIHR) Surgical Reconstruction and Microbiology Research Centre (SRMRC). The views expressed are those of the author(s) and not necessarily those of the NHS, the NIHR or the Department of Health.

Acknowledgments: The authors also appreciate and are thankful to University of Birmingham, the sports authorities and clubs who participated in the study.

Conflicts of Interest: The authors declare no conflict of interest.

\section{References}

1. Mani, K.; Cater, B.; Hudlikar, A. Cognition and Return to Work after Mild/Moderate Traumatic Brain Injury: A Systematic Review; Rumrill, P., Hendricks, D.J., Elias, E., Jacobs, K., Leopold, A., Nardone, A., Eds.; IOS Press Work: Amsterdam, The Netherlands, 2017; Volume 58, pp. 51-62.

2. Takada, K.; Sashika, H.; Wakabayashi, H.; Hirayasu, Y. Social participation and quality-of-life of patients with traumatic brain injury living in the community: A mixed methods study. Brain Inj. 2016, 30, 1590-1598. [CrossRef] [PubMed]

3. Taylor, C.A.; Bell, J.M.; Breiding, M.J.; Xu, L. Traumatic Brain Injury-Related Emergency Department Visits, Hospitalizations, and Deaths-United States, 2007 and 2013. MMWR Surveill Summ. 2017, 66, 1-16. [CrossRef] [PubMed]

4. Goldman, S.M.; Tanner, C.M.; Oakes, D.; Bhudhikanok, G.S.; Gupta, A.; Langston, J.W. Head injury and Parkinson's disease risk in twins. Ann. Neurol. 2006, 60, 65-72. [CrossRef] [PubMed]

5. Mild Traumatic Brain Injury Committee. Definition of mild traumatic brain injury. J. Head Trauma Rehabil. 1993, 8, 86-87. [CrossRef]

6. Broglio, S.P.; Collins, M.W.; Williams, R.M.; Mucha, A.; Kontos, A.P. Current and emerging rehabilitation for concussion: a review of the evidence. Clin. Sports Med. 2015, 34, 213-231. [CrossRef] [PubMed]

7. Heitger, M.H.; Jones, R.D.; Macleod, A.D.; Snell, D.L.; Frampton, C.M.; Anderson, T.J. Impaired eye movements in post-concussion syndrome indicate suboptimal brain function beyond the influence of depression, malingering or intellectual ability. Brain 2009, 132, 2850-2870. [CrossRef]

8. Langlois, J.A.; Rutland-Brown, W.; Wald, M.M. The epidemiology and impact of traumatic brain injury: A brief overview. J. Head Trauma Rehabil. 2006, 21, 375-378. [CrossRef]

9. Stern, R.A.; Riley, D.O.; Daneshvar, D.H.; Nowinski, C.J.; Cantu, R.C.; McKee, A.C. Long-term consequences of repetitive brain trauma: chronic traumatic encephalopathy. PM R 2011, 3, S460-S467. [CrossRef]

10. McKee, A.C.; Cantu, R.C.; Nowinski, C.J.; Hedley-Whyte, E.T.; Gavett, B.E.; Budson, A.E.; Santani, V.E.; Lee, H.; Kubilus, C.A.; Stern, R.A. Chronic traumatic encephalopathy in athletes: progressive tauopathy after repetitive head injury. J. Neuropathol. Exp. Neurol. 2009, 68, 709-735. [CrossRef]

11. Nemetz, P.N.; Leibson, C.; Naessens, J.M.; Beard, M.; Kokmen, E.; Annegers, J.F.; Kurland, L.T. Traumatic brain injury and time to onset of Alzheimer's disease: a population-based study. Am. J. Epidemiol. 1999, 149, 32-40. [CrossRef]

12. Guo, Z.; Cupples, L.A.; Kurz, A.; Auerbach, S.H.; Volicer, L.; Chui, H.; Green, R.C.; Sadovnick, A.D.; Duara, R.; DeCarli, C.; et al. Head injury and the risk of AD in the MIRAGE study. Neurology 2000, 54, 1316-1323. [CrossRef] [PubMed]

13. Das, M.; Mohapatra, S.; Mohapatra, S.S. New perspectives on central and peripheral immune responses to acute traumatic brain injury. J. Neuroinflammation. 2012, 9, 236. [CrossRef] [PubMed]

14. Chen, H.; Richard, M.; Sandler, D.P.; Umbach, D.M.; Kamel, F. Head injury and amyotrophic lateral sclerosis. Am. J. Epidemiol. 2007, 166, 810-816. [CrossRef] [PubMed] 
15. Yi, J.; Padalino, D.J.; Chin, L.S.; Montenegro, P.; Cantu, R.C. Chronic traumatic encephalopathy. Curr. Sports Med Rep. 2013, 12, 28-32. [CrossRef] [PubMed]

16. Collins-Praino, L.E.; Arulsamy, A.; Katharesan, V.; Corrigan, F. The effect of an acute systemic inflammatory insult on the chronic effects of a single mild traumatic brain injury. Behav. Brain Res. 2018, 336, $22-31$. [CrossRef] [PubMed]

17. McInnes, K.; Friesen, C.L.; MacKenzie, D.E.; Westwood, D.A.; Boe, S.G. Mild Traumatic Brain Injury (mTBI) and chronic cognitive impairment: A scoping review. PLoS ONE 2017, 12, e0174847. [CrossRef]

18. Thoma, R.J.; Cook, J.A.; McGrew, C.; King, J.H.; Pulsipher, D.T.; Yeo, R.A.; Monning, M.A.; Mayer, A.; Pommy, J.; Campbell, R.A. Convergent and discriminant validity of the ImPACT with traditional neuropsychological measures. Cogent Psychol. 2018, 5, 1-16. [CrossRef]

19. Werner, C.; Engelhard, K. Pathophysiology of traumatic brain injury. Br. J. Anaesth. 2007, 99, 4-9. [CrossRef]

20. Borlongan, C.; Acosta, S.; de la Pena, I.; Tajiri, N.; Kaneko, Y.; Lozano, D. Neuroinflammatory responses to traumatic brain injury: Etiology, clinical consequences, therapeutic opportunities. Neuropsychiatr. Dis. Treat. 2015, 97. [CrossRef]

21. Woodcock, T.; Morganti-Kossmann, M.C. The role of markers of inflammation in traumatic brain injury. Front. Neurol. 2013, 4,1-18. [CrossRef]

22. Jassam, Y.N.; Izzy, S.; Whalen, M.; McGavern, D.B.; El Khoury, J. Neuroimmunology of Traumatic Brain Injury: Time for a Paradigm Shift. Neuron. 2017, 95, 1246-1265. [CrossRef] [PubMed]

23. Gyoneva, S.; Ransohoff, R.M. Inflammatory reaction after traumatic brain injury: Therapeutic potential of targeting cell-cell communication by chemokines. Trends Pharmacol Sci. 2015, 36, 471-480. [CrossRef] [PubMed]

24. Loane, D.J.; Kumar, A. Microglia in the TBI brain: The good, the bad, and the dysregulated. Exp. Neurol. 2016, 275, 316-327. [CrossRef] [PubMed]

25. Thelin, E.P.; Tajsic, T.; Zeiler, F.A.; Menon, D.K.; Hutchinson, P.J.A.; Carpenter, K.L.H.; Morganti-Kossman, M.C.; Helmy, A. Monitoring the neuroinflammatory response following acute brain injury. Front. Neurol. 2017, 8, 1-14. [CrossRef] [PubMed]

26. Jin, Y.; Wang, R.; Yang, S.; Zhang, X.; Dai, J. Role of Microglia Autophagy in Microglia Activation After Traumatic Brain Injury. World Neurosurg. 2017, 100, 351-360. [CrossRef] [PubMed]

27. Hergenroeder, G.W.; Moore, A.N.; McCoy, J.P.; Samsel, L.; Ward, N.H.; Clifton, G.L.; Dash, P.K. Serum IL-6: A candidate biomarker for intracranial pressure elevation following isolated traumatic brain injury. $J$. Neuroinflammation. 2010, 7, 19. [CrossRef]

28. Kirchhoff, C.; Buhmann, S.; Bogner, V.; Stegmaier, J.; Leidel, B.A.; Braunstein, V.; Mutschler, W.; Biberthaler, P. Cerebrospinal IL-10 concentration is elevated in non-survivors as compared to survivors after severe traumatic brain injury. Eur. J. Med. Res. 2008, 13, 464-468.

29. Hill, L.J.; Di Pietro, V.; Hazeldine, J.; Davies, D.; Toman, E.; Logan, A.; Belli, A. Cystatin D (CST5): An ultra-early inflammatory biomarker of traumatic brain injury. Sci. Rep. 2017, 7, 5002. [CrossRef]

30. Licastro, F.; Hrelia, S.; Porcellini, E.; Malaguti, M.; Di Stefano, C.; Angeloni, C.; Carbone, I.; Simoncini, L.; Piperno, R. Peripheral inflammatory markers and antioxidant response during the post-acute and chronic phase after severe traumatic brain injury. Front. Neurol. 2016, 7, 1-12. [CrossRef]

31. Lovell, M.R.; Iverson, G.L.; Collins, M.W.; Podell, K.; Johnston, K.M.; Pardini, D.; Pardini, J.; Norwig, J.; Maroon, J.C. Measurement of Symptoms Following Sports-Related Concussion: Reliability and Normative Data for the Post-Concussion Scale. Appl. Neuropsychol. 2006, 13, 166-174. [CrossRef]

32. Carlozzi, N.E.; Kirsch, N.L.; Kisala, P.A.; Tulsky, D.S. An Examination of the Wechsler Adult Intelligence Scales, Fourth Edition (WAIS-IV) in Individuals with Complicated Mild, Moderate and Severe Traumatic Brain Injury (TBI). Clin. Neuropsychol. 2015, 29, 21-37. [CrossRef] [PubMed]

33. Till, C.; Colella, B.; Verwegen, J.; Green, R.E. Postrecovery Cognitive Decline in Adults with Traumatic Brain Injury. Arch. Phys. Med. Rehabil. 2008, 89, S25-S34. [CrossRef] [PubMed]

34. Maerlender, A.; Flashman, L.; Kessler, A.; Kumbhani, S.; Greenwald, R.; Tosteson, T.; McAllister, A. Examination of the Construct Validity of Impact ${ }^{\mathrm{TM}}$ Computerized Test, Traditional, and Experimental Neuropsychological Measures. Clin. Neuropsychol. 2010, 24, 1309-1325. [CrossRef] [PubMed]

35. Zeiler, F.A.; Thelin, E.P.; Czosnyka, M.; Hutchinson, P.J.; Menon, D.K.; Helmy, A. Cerebrospinal Fluid and Microdialysis Cytokines in Severe Traumatic Brain Injury: A Scoping Systematic Review. Front. Neurol. 2017, 10, 8. [CrossRef] 
36. Baron, W.; Metz, B.; Bansal, R.; Hoekstra, D.; de Vries, H. PDGF and FGF-2 Signaling in Oligodendrocyte Progenitor Cells: Regulation of Proliferation and Differentiation by Multiple Intracellular Signaling Pathways. Mol. Cell Neurosci. 2000, 15, 314-329. [CrossRef]

37. Kuroda, M.; Muramatsu, R.; Maedera, N.; Koyama, Y.; Hamaguchi, M.; Fujimura, H.; Yoshida, M.; Konishi, M.; Itoh, N.; Mochizuki, H.; et al. Peripherally derived FGF21 promotes remyelination in the central nervous system. J. Clin. Investig. 2017, 127, 3496-3509. [CrossRef]

38. Furusho, M.; Roulois, A.J.; Franklin, R.J.M.; Bansal, R. Fibroblast growth factor signaling in oligodendrocyte-lineage cells facilitates recovery of chronically demyelinated lesions but is redundant in acute lesions. Glia 2015, 63, 1714-1728. [CrossRef]

39. Chen, J.; Hu, J.; Liu, H.; Xiong, Y.; Zou, Y.; Huang, W.; Shao, M.; Wu, J.; Yu, L.; Wang, X.; et al. FGF21 Protects the Blood-Brain Barrier by Upregulating PPAR $\gamma$ via FGFR1/ $\beta$-klotho after Traumatic Brain Injury. J. Neurotrauma 2018, 35, 2091-2103. [CrossRef]

40. Huang, W.; Shao, M.; Liu, H.; Chen, J.; Hu, J.; Zhu, L.; Liu, F.; Wang, D.; Zou, Y.; Xiong, Y.; et al. Fibroblast growth factor 21 enhances angiogenesis and wound healing of human brain microvascular endothelial cells by activating PPAR $\gamma$. J. Pharmacol. Sci. 2019, 140, 120-127. [CrossRef]

41. Hsuchou, H.; Pan, W.; Kastin, A.J. The fasting polypeptide FGF21 can enter brain from blood. Peptides 2007, 28, 2382-2386. [CrossRef]

42. Raeber, M.E.; Zurbuchen, Y.; Impellizzieri, D.; Boyman, O. The role of cytokines in T-cell memory in health and disease. Immunol. Rev. 2018, 283, 176-193. [CrossRef] [PubMed]

43. Jana, M.; Mondal, S.; Jana, A.; Pahan, K. Interleukin-12 (IL-12), but not IL-23, induces the expression of IL-7 in microglia and macrophages: implications for multiple sclerosis. Immunology 2014, 141, 549-563. [CrossRef] [PubMed]

44. Yuan, X.; Wu, Q.; Wang, P.; Jing, Y.; Yao, H.; Tang, Y.; Han, R.; He, W.; Li, Z.; Zhang, H.; et al. Intraspinal administration of interleukin-7 promotes neuronal apoptosis and limits functional recovery through JAK/STAT5 pathway following spinal cord injury. Biochem. Biophys. Res. Commun. 2019, 514, 1023-1029. [CrossRef] [PubMed]

45. Juengst, S.B.; Kumar, R.G.; Failla, M.D.; Goyal, A.; Wagner, A.K. Acute Inflammatory Biomarker Profiles Predict Depression Risk Following Moderate to Severe Traumatic Brain Injury. J. Head Trauma Rehabil. 2015, 30, 207-218. [CrossRef] [PubMed]

46. Soroosh, P.; Doherty, T.A.; So, T.; Mehta, A.K.; Khorram, N.; Norris, P.S.; Scheu, S.; Pfeffer, K.; Ware, C.; Croft, M. Herpesvirus entry mediator (TNFRSF14) regulates the persistence of $\mathrm{T}$ helper memory cell populations. J. Exp. Med. 2011, 208, 797-809. [CrossRef]

47. Tamada, K.; Shimozaki, K.; Chapoval, A.I.; Zhu, G.; Sica, G.; Flies, D.; Boone, T.; Hsu, H.; Fu, Y.X.; Nagata, S.; et al. Modulation of T-cell-mediated immunity in tumor and graft-versus-host disease models through the LIGHT co-stimulatory pathway. Nat. Med. 2000, 6, 283-289. [CrossRef]

48. Shaikh, R.B.; Santee, S.; Granger, S.W.; Butrovich, K.; Cheung, T.; Kronenberg, M.; Cheroutre, H.; Ware, C.F. Constitutive Expression of LIGHT on T Cells Leads to Lymphocyte Activation, Inflammation, and Tissue Destruction. J. Immunol. 2001, 167, 6330-6337. [CrossRef]

49. Jernås, M.; Malmeström, C.; Axelsson, M.; Nookaew, I.; Wadenvik, H.; Lycke, J.; Olsson, B. MicroRNA regulate immune pathways in T-cells in multiple sclerosis (MS). BMC Immunol. 2013, 14, 32. [CrossRef]

50. Semple, B.D.; Bye, N.; Rancan, M.; Ziebell, J.M.; Morganti-Kossmann, M.C. Role of CCL2 (MCP-1) in Traumatic Brain Injury (TBI): Evidence from Severe TBI Patients and CCL2-/- Mice. J. Cereb. Blood Flow Metab. 2010, 30, 769-782. [CrossRef]

51. Berman, J.W.; Guida, M.P.; Warren, J.; Amat, J.; Brosnan, C.F. Localization of monocyte chemoattractant peptide-1 expression in the central nervous system in experimental autoimmune encephalomyelitis and trauma in the rat. J. Immunol. 1996, 156, 3017-3023.

52. Glabinski, A.R.; Balasingam, V.; Tani, M.; Kunkel, S.L.; Strieter, R.M.; Yong, V.W.; Ransohoff, R.M. Chemokine monocyte chemoattractant protein-1 is expressed by astrocytes after mechanical injury to the brain. $J$. Immunol. 1996, 156, 4363-4368. [PubMed]

53. Yang, G.; Meng, Y.; Li, W.; Yong, Y.; Fan, Z.; Ding, H.; Wei, Y.; Luo, J.; Ke, Z.J. Neuronal MCP-1 Mediates Microglia Recruitment and Neurodegeneration Induced by the Mild Impairment of Oxidative Metabolism. Brain Pathol. 2011, 21, 279-297. [CrossRef] [PubMed] 
54. Rhodes, J.; Sharkey, J.; Andrews, P. Serum IL-8 and MCP-1 Concentration Do Not Identify Patients with Enlarging Contusions After Traumatic Brain Injury. J. Trauma Inj. Infect Crit. Care 2009, 66, 1591-1598. [CrossRef] [PubMed]

55. Poniatowski, Ł.A.; Wojdasiewicz, P.; Krawczyk, M.; Szukiewicz, D.; Gasik, R.; Kubaszewski, Ł.; Kurkowska-Jastrzebska, I. Analysis of the Role of CX3CL1 (Fractalkine) and Its Receptor CX3CR1 in Traumatic Brain and Spinal Cord Injury: Insight into Recent Advances in Actions of Neurochemokine Agents. Mol. Neurobiol. 2017, 54, 2167-2188. [CrossRef] [PubMed]

56. Sheridan, G.K.; Murphy, K.J. Neuron-glia crosstalk in health and disease: fractalkine and CX 3 CR1 take centre stage. Open Biol. 2013, 3, 130181. [CrossRef] [PubMed]

57. Boehme, S.A.; Lio, F.M.; Maciejewski-Lenoir, D.; Bacon, K.B.; Conlon, P.J. The Chemokine Fractalkine Inhibits Fas-Mediated Cell Death of Brain Microglia. J. Immunol. 2000, 165, 397-403. [CrossRef]

58. Rancan, M.; Bye, N.; Otto, V.I.; Trentz, O.; Kossmann, T.; Frentzel, S.; Morganti-Kossman, M.C. The Chemokine Fractalkine in Patients with Severe Traumatic Brain Injury and a Mouse Model of Closed Head Injury. J. Cereb. Blood Flow Metab. 2004, 24, 1110-1118. [CrossRef]

59. Helmy, A.; Carpenter, K.L.; Menon, D.K.; Pickard, J.D.; Hutchinson, P.J. The Cytokine Response to Human Traumatic Brain Injury: Temporal Profiles and Evidence for Cerebral Parenchymal Production. J. Cereb. Blood Flow Metab. 2011, 31, 658-670. [CrossRef]

60. Yakoub, K.M.; Davies, D.J.; Su, Z.; Bentley, C.; Forcione, M.; Toman, E.; Hammond, D.; Watson, C.N.; Bishop, J.; Cooper, L.; et al. Investigation into repetitive concussion in sport (RECOS): study protocol of a prospective, exploratory, observational cohort study. BMJ Open 2019, 9, e029883. [CrossRef]

61. Echemendia, R.J.; Meeuwisse, W.; McCrory, P.; Davis, G.A.; Putukian, M.; Leddy, J.; Makdissi, M.; Sullivan, S.J.; Broglio, S.P.; Raftery, M.; et al. The Sport Concussion Assessment Tool 5th Edition (SCAT5): Background and rationale. Br. J. Sports Med. 2017, 51, 84850.

(C) 2020 by the authors. Licensee MDPI, Basel, Switzerland. This article is an open access article distributed under the terms and conditions of the Creative Commons Attribution (CC BY) license (http://creativecommons.org/licenses/by/4.0/). 